Zeszyty Naukowe Szkoły Głównej Gospodarstwa Wiejskiego

Ekonomika i Organizacja Gospodarki Żywnościowej nr 119, 2017: 65-85

DOI 10.22630/EIOGZ.2017.119.26

Justyna Franc-Dąbrowska

Katedra Finansów

Szkoła Główna Gospodarstwa Wiejskiego w Warszawie

\title{
Luminarze finansów agrobiznesu, stan obecny i perspektywy
}

\section{Wprowadzenie}

Ewolucja ludzkości jest niezmiennie stała. Dokonuje się. Bez względu na czas i miejsce. Część ludzkich potrzeb pozostaje taka sama, inne ulegają ciaggłym zmianom. Niesie to brzemienne skutki zarówno w życiu codziennym każdego człowieka z osobna, jak i ludzkości jako całości. W niektórych rejonach świata jednostki bogacą się niewspółmiernie w odniesieniu do zamożności (ubóstwa) całych społeczności w innych regionach kuli ziemskiej. Bez wątpienia skutkiem zmian ewolucyjnych są pogłębiające się dysproporcje w potrzebach ludzkich i możliwościach ich zaspokajania - w zakresie własnych zasobów (w tym szczególnie pieniężnych).

Jednym z podstawowych obszarów podlegających ewolucji są finanse, poczynając od pojedynczej monety - traktowanej jako środek płatniczy, a kończąc na całej nauce finansów. Jak trudne do jednoznacznego określenia i ważne nie tylko dla pojedynczych osób czy gospodarek poszczególnych krajów są finanse, świadczą rozległe skutki kryzysu finansowego, zapoczątkowanego w 2007 roku. Mimo licznych regulacji, rozbudowanych systemów analitycznych i metod oceny, nie zawsze możliwe było zareagowanie w odpowiednim momencie i we właściwej skali na symptomy problemów w ,świecie finansów”. Konieczne zatem jest dalsze pogłębianie badań z zakresu ewolucji operacji finansowych i wpływu decyzji człowieka właśnie na ,świat finansów”.

Od dłuższego już czasu wyraźnie widoczne są ewolucyjne zmiany w postrzeganiu zjawisk finansowych. Za moment przełomowy można uznać nagrody Banku Szwecji im. Alfreda Nobla w dziedzinie nauk ekonomicznych przyznane przez Komitet Noblowski Herbertowi Simonowi w 1978 roku za teorię ogra- 
niczonej racjonalności oraz szczególnie Danielowi Kahnemanowi w 2002 ro$\mathrm{ku}$ za zastosowanie narzędzi z psychologii $\mathrm{w}$ badaniach ekonomicznych, ze szczególnym uwzględnieniem teorii perspektywy ${ }^{1}$. Historyczne odchodzenie od paradygmatu finansów i próby uwzględniania coraz większej liczby czynników w ocenie sytuacji finansowej przedsiębiorstw skłaniają ku interdyscyplinarnemu podejściu, jednak o tej kwestii w dalszej części rozważań. Podobnie przełomowe znaczenie ma nagroda przyznana w 2013 roku Robertowi J. Shillerowi, Eugene Famie i Larsowi P. Hansenowi w zakresie ekonomii finansowej, w tym szczególnie za empiryczne badania cen aktywów ${ }^{2}$.

\section{Koryfeusze finansów agrobiznesu - rys historyczny}

Gdzie są korzenie finansów? Zapewne tam, gdzie korzenie ludzkości. Bez wątpienia od zarania dziejów człowiek dokonywał wymiany, w sposób adekwatny do poziomu rozwoju gatunku ludzkiego. Niezależnie od formy i nazwy, pieniądz pełni tę samą funkcję, umożliwiając człowiekowi zaspokojenie podstawowych potrzeb poprzez wymianę. Pierwszy papierowy pieniądz wykonano w Chinach w 119 roku p.n.e. podczas panowania zachodniej dynastii Han (jako dowód depozytowy). Interesujący był widniejący na nim napis: „Cokolwiek robisz, rób ostrożnie” [Świat Druku The World of Printing... 2009]. Jak zauważa Mikołaj Malinowski, trzy tysiące lat p.n.e. na terenach położonych między Tygrysem a Eufratem, w jednej z najstarszych pisemnych kultur świata, narodził się interesujący system walutowy bazujący na zbożu, później środkiem płatniczym były zwierzęta, metalowe narzędzia, naczynia, muszle czy ozdoby. Pierwsze monety wytwarzano w Rzymie już w IV w p.n.e. [Malinowski 2016]. Pierwotnie pieniądz miał zatem formę bezpośrednio związaną z rolniczą działalnością człowieka - nawet jeśli uznamy, że trudno tę działalność uznać za rolnictwo, to bez wątpienia była ona związana z wytwarzaniem żywności niezbędnej do przeżycia każdej istoty.

Można zatem uznać, że wraz z wymianą produktów/towarów czy usług między ludźmi, niezależnie od formy zapłaty, pojawiły się zjawiska finansowe, a zatem i finanse. Co więcej, pojawily się właśnie w bezpośrednim związku

\footnotetext{
${ }^{1}$ The Sveriges Riksbank Prize in Economic Sciences in Memory of Alfred Nobel 2002, https: //www.nobelprize.org/nobel_prizes/economic-sciences/laureates/2002/ [dostęp: 05.11.2016].

${ }^{2}$ The Sveriges Riksbank Prize in Economic Sciences in Memory of Alfred Nobel 2013, https: //www.nobelprize.org/nobel_prizes/economic-sciences/laureates/2013 [dostęp: 05.11.2016]; por. także Profesorowie Eugene F. Fama, Lars Peter Hansen i Robert J. Shiller zostali lauretami nagrody Nobla z dziedziny ekonomii za empiryczne analizy cen aktywów - ogłoszono w poniedziałek, https://www.forbes.pl/wiadomości/nobel-z-ekonomii-2013-fama-hansen-schiller/0gr7je [dostęp: 20.11.2016].
} 
z działalnością rolniczą pojedynczego człowieka, którego dzisiaj nazwalibyśmy przedsiębiorcą. Co prawda stwierdzenie to stoi w opozycji do klasycznego podejścia do finansów, bo Stanisław Flejterski i Beata Świecka, podają, że finanse (wywodzace się z łacińskiego finire) pojawiły się w średniowieczu wraz z rozwojem pieniądza i gospodarki pieniężnej [Flejterski i Świecka 2005]. Finansiści twierdzą także, że finanse to ogół zjawisk i stosunków finansowych powstających w związku z tworzeniem, transferem, gromadzeniem i wydatkowaniem środków pieniężnych [Flejterski i Świecka 2005].

Podchodząc jednak do finansów filozoficznie, wydaje się, że właściwe jest poszerzenie tego podejścia i uwzględnienie także operacji zapłaty za towar w innej formie niż tylko pieniężnej (chociażby system opłat zbożowych, zwierzętami, muszlami, czy innymi cennymi dla danej społeczności rzeczami). Autorka proponuje zatem - nawiązując do korzeni ludzkości - poszerzyć definicję finansów, wcale nie traktując jej jako bardziej współczesną, a wręcz przeciwnie wiążąc ją z początkami człowieka i prostymi operacjami wymiany między ludźmi.

Finanse ewoluują. To nie ulega wątpliwości. Rozpoczynając od największych osiagnięć w nauce finansów, można wymienić takie wybitne postaci jak Harry Markowitz i jego teoria portfelowa [1952], czyli pionierskie prace w teorii ekonomii finansowej, Franco Modigliani i Merton H. Miller z przełomowymi opracowaniami z zakresu struktury kapitału [1958, 1961 i 1963], Herbert A. Simon z ,wywrotową" jak na owe czasy teorią ograniczonej racjonalności ${ }^{3}$. Kolejnym milowym krokiem w nauce finansów były badania Daniela Kahnemana i Amosa Tversky'ego (1979), których stwierdzenia spowodowały silne poszerzenie postrzegania finansów, a tym samym pola badawczego nauki o finansach. Odwołując się do współczesnego dorobku noblistów, należy podkreślić, że m.in. Jan Tinbergen (noblista z 1969 roku) w swoich pracach wiele miejsca poświęcił teoriom działania rynków rolnych [Szaleniec 2009]. Nagrodę otrzymał za wkład w rozwój ekonometrii, jednak skupiał się również na badaniach sektora rolnego [Cornelisse i van Dijk 2006]. Kolejny noblista Joseph E. Stiglitz [2001], w swojej działalności naukowej wyjaśniał główne przyczyny interwencji w nowoczesnym, światowym rolnictwie wskazując na wysoki poziom ryzyka w działalności rolniczej oraz nieskuteczność w zapobieganiu temu ryzyku. Podobnie twierdzi Jerzy Wilkin [Wigier 2013] ${ }^{4}$. A zatem rolnictwo i zjawiska

\footnotetext{
${ }^{3}$ The Sveriges Riksbank Prize in Economic Sciences in Memory of Alfred Nobel 1978, https:// www. nobelprize.org/nobel_prizes/economic-sciences/laureates/1978/

${ }^{4}$ Por. także: Stiglitz J.E., 1987, Some Theoretical Aspects of Agricultural Policies, the World Bank Research Observer, vol. 2, no. 1 (Jan., 1987): 43-60; por. także: Sah R.K., Stiglitz J.E., 1987, The taxation and pricing of agricultural and industrial goods in developing economies [w:] (red.) D.M.G. Newbery, N.H. Stern. The theory of taxation for developing countries, Chapter 16, 426461, Oxford University Press, New York.
} 
w nim zachodzące są podejmowane przez wielu wybitnych badaczy, a każdy z tych obszarów badań, jeśli nie bezpośrednio, to przynajmniej częściowo dotyka kwestii finansów ${ }^{5}$.

Jeśli odejdziemy od absolutyzmu w postrzeganiu zjawisk finansowych, pojawia się miejsce na ważny obszar badań - finanse gospodarstw i przedsiębiorstw rolniczych, w szerszym ujęciu określane jako finanse agrobiznesu. Co więcej, wybitni polscy prekursorzy badania zjawisk finansowych w podmiotach rolniczych tworzyli już w pierwszych latach XX wieku. Bez wattpienia luminarzem finansów agrobiznesu był Władysław Dominik Grabski (1874-1938), rektor (1926-1928) i Prorektor (1928-1929) Szkoły Głównej Gospodarstwa Wiejskiego w Warszawie, który kwestie finansów agrobiznesu poruszał m.in. w takim dziele jak: Wskaźniki $i$ nożyce cen w rolnictwie (1929). Grabski nie był w tym czasie jedyną osobą podejmujące trudną tematykę finansów gospodarstw i przedsiębiorstw rolniczych. Ogromny dorobek pozostawił Stefan Moszczeński, który zajmował się kwestiami metodycznymi finansów podmiotów rolniczych, tworząc w SGGW szkołę matematyczną w ekonomice rolnictwa. Najważniejsze dzieła Moszczeńskiego traktujące o problematyce finansów zaprezentowano w tabeli 1.

Nie można mówić o początkach nauki finansów agrobiznesu bez wskazania dorobku Ryszarda Manteuffla-Schoege, który stworzył szkołę ekonomistów

Tabela 1

Wybrane dzieła Stefana Moszczeńskiego, traktujące o problematyce finansów agrobiznesu

\begin{tabular}{|l|c|}
\hline \multicolumn{1}{|c|}{ Tytuł opracowania } & Rok wydania \\
\hline Poszukiwanie cenności gruntów i majątków wiejskich & 1920 \\
\hline $\begin{array}{l}\text { O korzyściach i sposobach prowadzenia rachunków w drobnym } \\
\text { gospodarstwie rolnym }\end{array}$ & 1921 \\
\hline Metody wyceniania ziemi w obliczu reformy rolnej & 1927 \\
\hline $\begin{array}{l}\text { Filozofia rachunkowości rolniczej: (analiza, krytyka pojęć i metod } \\
\text { rachunkowych) }\end{array}$ & 1929 \\
\hline $\begin{array}{l}\text { Ujednostajnienie metod i sposób opracowania metod statystycznych } \\
\text { w biurach rachunkowości rolniczej }\end{array}$ & 1929 \\
\hline $\begin{array}{l}\text { Jakie korzyści może odnieść rolnik, prowadząc uproszczona } \\
\text { rachunkowośc do wymiaru podatku dochodowego }\end{array}$ & 1935 \\
\hline Znaczenie rachunkowości podwójnej w rolnictwie a w ogrodnictwie & 1935 \\
\hline O potrzebie katedry rachunkowości w akademickich szkołach rolniczych & 1938 \\
\hline Rachunkowość gospodarstw wiejskich & 1948 \\
\hline
\end{tabular}

Źródło: Opracowanie własne na podstawie zasobów Biblioteki Narodowej.

\footnotetext{
${ }^{5}$ Krzysztof Jajuga [2013] wskazuje na co najmniej 6 nagród, które otrzymali wybitni ekonomiści zajmujący się finansami. Poza wymienionymi są to także: James Tobin (1985), Robert Merton i Myron Sholes (1997) oraz Robert Engle (2003).
} 
rolnych i kult potrzeby prowadzenia badań $\mathrm{w}$ gospodarstwach i przedsiębiorstwach rolniczych. O ile twórczość Moszczeńskiego skupiała się na dwóch zasadniczych obszarach, czyli rachunkowości rolnej i wycenie w rolnictwie, o tyle Manteuffel-Schoege poszedł dalej w zgłębianiu tajemnic ,świata finansów przedsiębiorstw rolniczych", podejmując trudne zagadnienia kosztów produkcji w gospodarstwach chłopskich, efektywności inwestycji rolniczych czy wykorzystania danych $\mathrm{z}$ rachunkowości do celów zarządczych. Jako największe dzieło z zakresu finansów Manteuffla-Schoege należy wskazać pracę z 1961 roku $R a-$ chunkowość rolnicza: Księgowość rolnicza; systemy, metody, technika. Do prac tego naukowca poruszających kwestie finansów gospodarstw rolniczych zaliczyć należy przede wszystkim te zawarte w tabeli 2 .

Tabela 2

Wybrane dzieła Ryszarda Manteuffla-Schoege traktujące o problematyce finansów agrobiznesu

\begin{tabular}{|l|c|}
\hline \multicolumn{1}{|c|}{ Tytuł opracowania } & Rok wydania \\
\hline $\begin{array}{l}\text { Badania kosztów produkcji w indywidualnych gospodarstwach } \\
\text { chłopskich w 1948/49 r. }\end{array}$ & 1950 \\
\hline Rachunkowość rolnicza: Księgowość rolnicza; systemy, metody, technika & 1961 \\
\hline Efektywność inwestycji rolniczych & 1963 \\
\hline $\begin{array}{l}\text { Różnicowy rachunek opłacalności w rolnictwie: w oparciu o metodę } \\
\text { ceteris paribus }\end{array}$ & 1964 \\
\hline $\begin{array}{l}\text { Księgowość rolnicza w podejmowaniu decyzji kierowniczych: materiały } \\
\text { do sesji, która odbyła się 6 czerwca 1968 r. (red. nauk. Ryszard } \\
\text { Manteuffel, Andrzej Bernacki) }\end{array}$ & 1970 \\
\hline
\end{tabular}

Źródło: Opracowanie własne na podstawie zasobów Biblioteki Narodowej.

Wymieniając wybitnych twórców finansów przedsiębiorstw agrobiznesu, należy wskazać także wychowankę Moszczeńskiego - Hannę Paszkowiczową (1892-1961). Była ona jedną z tych osób, które miały swój aktywny wkład w organizację tajnego nauczania w SGGW w Warszawie ${ }^{6}$. Praca naukowa Paszkowiczowej skupiała się ściśle na kwestiach finansów przedsiębiorstw rolniczych, w tym m.in. na zarządzaniu kapitałem obrotowym, rachunkowości, ujęciu kasowym operacji gospodarczych, zastosowaniu matematyki w kalkulacjach. Wybrane prace Paszkowiczowej zaprezentowano w tabeli 3.

Podchodząc historycznie do osób zasłużonych dla rozwoju finansów w rolnictwie, należy wspomnieć również o Teresie Marszałkowicz (1924-1998), która była twórcą szkoły naukowej z zakresu statystyki teoretycznej i ekonometrii oraz informatyki, a jej prace miały przełomowe znaczenie w zastosowaniu tych dyscyplin w badaniach ekonomiczno-rolniczych [Borkowski 2006].

\footnotetext{
${ }^{6} \mathrm{http}: / /$ www.passa.waw.pl/index.php/artykul/jak-przetrwaa-wojne-najwieksza-polska-uczelniarolnicza,27?ref $=5$ [dostęp: 16.11.2016].
} 
Tabela 3

Wybrane dzieła Hanny Paszkowiczowej traktujące o problematyce finansów agrobiznesu

\begin{tabular}{|l|c|}
\hline \multicolumn{1}{|c|}{ Tytuł opracowania } & Rok wydania \\
\hline Application des méthodes mathénatuqyes á la comptabilité agricole & 1932 \\
\hline Zastosowanie metod matematycznych do zagadnień kalkulacyjnych & 1935 \\
\hline Rachunkowość podwójna w świetle algebry & 1936 \\
\hline Zastosowanie matematyki do badań rachunkowych & 1936 \\
\hline Analiza kapitału obrotowego & 1938 \\
\hline Dziennik kasowy & 1945 \\
\hline
\end{tabular}

Źródło: Opracowanie własne na podstawie zasobów Biblioteki Narodowej.

\section{Początek XXI wieku - zakres i wyniki badań}

Turbulentne otoczenie powoduje, że z upływem czasu problemy świata finansów agrobiznesu skłaniają do poszerzania zakresu badań. O ile pierwsza połowa XX wieku zdominowana była kwestiami wyceny, rachunku opłacalności i ewidencji księgowej, o tyle przełom wieków XIX i XX oraz początek XXI wieku nacechowane są wielowątkowością i szerokim zakresem kwestii wymagających zbadania i rozstrzygnięcia.

Współczesne badania z zakresu finansów przedsiębiorstw rolniczych można ująć w kilka grup tematycznych, takich jak ${ }^{7}$ :

1. Metodyka oceny sytuacji finansowej (ze szczególnym uwzględnieniem płynności, zadłużenia i wyceny):

a) gospodarstw rolniczych (tzw. chłopskich, gdzie występuje jedność gospodarstwa domowego i przedsiębiorstwa),

b) przedsiębiorstw rolniczych,

c) spółek giełdowych i spółek przetwórstwa rolno-spożywczego;

2. Problem ewidencji, a w zasadzie w wielu wypadkach jej braku, operacji gospodarczych;

3. Inwestycje i innowacje w podmiotach agrobiznesu i ich efektywność:

a) nurt ogólny,

b) nurt ekologiczny,

c) nurt energetyczny;

4. Kredyty dla rolnictwa, także na zasadach preferencyjnych oraz problem bankructw w agrobiznesie;

\footnotetext{
${ }^{7}$ Zaproponowana systematyka nie wyczerpuje wszystkich obszarów badań, ma jednak na celu próbę ich uporządkowania w większe agregaty. Systematyka ta ma charakter otwarty.
} 
5. Wspólna polityka rolna (WPR) i jej wpływ na sytuację finansową podmiotów rolniczych;

6. Preferencyjne, a może niekoniecznie opodatkowanie działalności rolniczej podatkiem rolnym;

7. Preferencyjny system ubezpieczenia rolników w Kasie rolniczego ubezpieczenia społecznego (KRUS);

8. Ryzyko w rolnictwie, silnie determinowane przez m.in.:

a) warunki przyrodnicze,

b) gospodarowanie z organizmami żywymi,

c) awersję przedsiębiorców rolnych do podejmowania ryzyka finansowego;

9. Struktura demograficzna i mała mobilność przedsiębiorców rolnych wynikająca ze specyfiki działalności.

Jednym z obszarów szeroko analizowanych - jednak nierozstrzygniętych jednoznacznie - pozostaje kwestia oceny sytuacji finansowej gospodarstw i przedsiębiorstw rolniczych. Problemy metodyczne w ocenie zjawisk finansowych dotyczą całej nauki finansów, a uwagę na tę kwestię w sferze finansów państwa zwrócił Stanisław Owsiak [2013]. Ten zakres badań pozostaje w obszarze zainteresowania ze względu na kwestie metodyczne, które różnicują podmioty gospodarcze spoza agrobiznesu i te funkcjonujące w rolnictwie. Niezwykle interesującym zagadnieniem jest problematyka braku płynności finansowej i zatorów płatniczych ,nękających” polskich rolników. Z badań Stanisława Mańki, Tadeusza Sobczyńskiego i Romana Sassa wynika, że dla gospodarstw rolniczych charakterystyczne są bardzo wysokie wskaźniki płynności, do tego silnie zróżnicowane w różnych krajach Unii Europejskiej (EU). Na przykład średni poziom wskaźnika płynności bieżącej dla gospodarstw rolniczych w Belgii w latach 1989-2005 wyniósł 346,05, podczas gdy w Wielkiej Brytanii 1,87 [Mańko, Sobczyński i Sass 2008], co m.in. wynika ze znacznego zróżnicowania rolnictwa w tych krajach. Podobne wyniki badań uzyskali m.in. Mirosław Wasilewski i Agnieszka Gałecka [2010]. Z kolei inne wyniki badań wskazują, że w wielu polskich przedsiębiorstwach rolniczych poziomy wskaźników płynności oscylują w granicach charakterystycznych dla podmiotów spoza agrobiznesu [Franc-Dąbrowska 2008a, b].

Bardzo ważną inicjatywą realizowaną od 1995 roku w Instytucie Ekonomiki Rolnictwa i Gospodarki Żywnościowej - Państwowym Instytucie Badawczym jest lista 300 najlepszych przedsiębiorstw rolnych. Początkowo nad Rankingiem 300 czuwał zespół Wacława Guzewicza, a od kilku już lat zespół Jacka Kulawika. Początkowo klasyfikowanie przedsiębiorstw rolniczych dokonywane było za pomocą pojedynczego kryterium (np. poziomu przychodów ze sprzedaży, wskaźnika wartości dodanej, rentowności sprzedaży), później opracowano mia- 
ry wielokryterialne ${ }^{8}$. Jest to cenny obszar badań, gdyż uwzględnia ocenę podstawowych parametrów finansowych przedsiębiorstw/gospodarstw rolniczych i może służyć jako punkt odniesienia do dalszych analiz. Okazuje się również, że w ramach Rankingu 300 przedsiębiorstwa cechują się zróżnicowanymi poziomami wskaźników płynności, rentowności czy zadłużenia. Nie jest zatem łatwe do zinterpretowania, czy i w jakich warunkach ich poziomy są właściwe. Znaczne zróżnicowanie wskaźników płynności (a także innych klasycznych miar oceny sytuacji finansowej przedsiębiorstw) występuje w zależności od typu produkcyjnego, kierunku i struktury produkcji rolniczej. Wydaje się zatem, że warto kontynuować ten obszar badań i podejmować próby standaryzacji miar oceny sytuacji finansowej różnych grup podmiotów agrobiznesu.

$\mathrm{Z}$ zagadnieniem oceny płynności finansowej przedsiębiorstw rolniczych wiąże się równie ważna kwestia określenia i oceny potencjału zadłużeniowego tych jednostek. Nie chodzi o poszukiwanie optymalnej struktury kapitału, ale ustalenie, w jakich warunkach przedsiębiorcy rolni mogliby zadłużać się korzystnie z punktu widzenia długoterminowego bezpieczeństwa finansowego, a zatem i możliwości rozwoju. Jak dotychczas stwierdzono, że o ile w przedsiębiorstwach rolniczych (prowadzących ewidencję na zasadach ogólnych) zakres podejmowania decyzji o zadłużeniu - jak i jego skutki - bliskie są relacjom występującym w przedsiębiorstwach spoza agrobiznesu, o tyle w gospodarstwach rolniczych występuje awersja do ryzyka i unikanie zadłużania gospodarstwa [Sulewski 2015]. Po części należy wiązać tę sytuację z kolejną kwestią podejmowaną $w$ badaniach gospodarstw i przedsiębiorstw rolniczych, $\mathrm{tj}$. wyceną potencjału wzrostu wartości dla właścicieli (a także użytkowników) gospodarstw i przedsiębiorstw rolniczych. Jest to zakres badań stosunkowo rzadko podejmowany, szczególnie w odniesieniu do gospodarstw, $\mathrm{z}$ tego powodu, że nierozstrzygnięte zostały dylematy rozdziału części gospodarstwa będącego „firmą” i tej, która uznawana jest za gospodarstwo domowe [Bereżnicka 2013]. Z tym dalej wiąże się kwestia wyceny poszczególnych składników majątku i rozdziału kosztów przynależnych procesowi produkcyjnemu i tych związanych z gospodarstwem domowym. Dalej pojawia się problem identyfikacji zagrożeń i określenia oraz oceny ryzyka takiej działalności (co przenosi się na konkretne decyzje finansowe, chociażby w zakresie udzielania pożyczek i kredytów przedsiębiorcom rolnym). Aby zweryfikować sytuację finansową podmiotów gospodarczych, niezbędne są badania $\mathrm{z}$ uwzględnieniem wyniku finansowego generowanego na różnych poziomach działalności [Franc-Dąbrowska 2006].

Rozstrzygnięcie dylematów metodycznych związanych z oceną sytuacji finansowej podmiotów agrobiznesu jest niezbędne, aby łatwiejsze (a czasami

\footnotetext{
${ }^{8}$ http://www.ierigz.waw.pl/prace-badawcze/ranking-300/historia-i-zasady [dostęp: 18.11.2016].
} 
w ogóle możliwe) było identyfikowanie tych jednostek, które nie rokują dalszego funkcjonowania i zagrożone są bankructwem. Jest to również obszar badań podejmowanych $\mathrm{w}$ odniesieniu do gospodarstw i przedsiębiorstw rolniczych. $\mathrm{W}$ toku prowadzonych analiz opracowane zostały modele klasyfikacyjne umożliwiające prognozowanie sytuacji finansowej gospodarstw rolniczych [Kisielińska 2008] oraz zidentyfikowane zostały przyczyny bankructwa przedsiębiorstw agrobiznesu [Boratyńska 2010]. Podjęte zostały zatem już prace pozwalające na dostosowanie metodyki prognozowania upadłości do specyfiki przedsiębiorstw agrobiznes $^{9}$, a także badania pozwalające na weryfikowanie sytuacji finansowej przedsiębiorstw rolniczych $\mathrm{z}$ zastosowaniem wybranych modeli panelowych [Franc-Dąbrowska 2009].

Bezpośrednio związane z problematyką oceny sytuacji finansowej podmiotów rolniczych (a tym samym identyfikacji ich problemów finansowych) jest zagadnienie bezpieczeństwa finansowego. Szczególnie ważne w tym kontekście jest uwzględnienie rozwiązań wspólnej polityki rolnej (WPR) i jej oddziaływania na sytuację finansową przedsiębiorców rolnych. Instrumenty redystrybucji dochodowej, takie jak płatności bezpośrednie mają zasadniczy wpływ na wybory dokonywane przez rolników, a w konsekwencji ich dochody. Jak bardzo złożony jest problem kształtu, zmian, a zatem i wpływu WPR na sytuację w rolnictwie - a tym samym sytuację finansową rolników - wskazują cykliczne badania zespołu Jacka Kulawika, publikowane w kolejnych raportach z cyklu Dopłaty bezpośrednie i dotacje budzetowe a finanse oraz funkcjonowanie gospodarstw i przedsiębiorstw rolniczych. Badania prowadzone są wielowątkowo, a ich celem było m.in. określenie ,wieloaspektowego i wieloletniego oddziaływania dotychczasowych subsydiów na ekonomikę i finanse polskich gospodarstw (analiza ex post) oraz określenie skutków wsparcia, które będzie dostępne w nowej perspektywie budżetowej UE (badania ex ante)" [Kulawik 2013]. Do trzech długoterminowych celów WPR, należą:

- dochodowa produkcja żywności,

- zrównoważone gospodarowanie zasobami naturalnymi oraz działania na rzecz klimatu,

- zrównoważony rozwój terytorialny,

Z kolei w ramach I filaru od 2015 roku celami są:

- płatność za praktyki rolnicze korzystne dla klimatu i środowiska, czyli tak zwane zazielenienie, od których realizacji uzależnione będzie przyznanie części płatności obszarowych (do 30\% kwoty koperty krajowej),

- płatności dla małych gospodarstw (do 3 ha GO),

- płatności dla młodych rolników,

\footnotetext{
${ }^{9}$ Por. pozycję książkową Adamskiej i Mączyńskiej [2013], gdzie w wielu miejscach poruszane są kwestie specyfiki identyfikacji zagrożenia bankructwem podmiotów rolniczych.
} 
- płatności związane z produkcją,

- płatności z tytułu obszarów o ograniczeniach naturalnych [Kulawik 2013].

$\mathrm{W}$ ramach tych celów pojawiają się założenia, które stawiają przed przedsiębiorcami rolnymi wiele warunków do spełnienia, aby zwiększyć poziom dochodów/zysków. Pewne uszczegółowienie problematyki wpływu subsydiów na sytuację finansową przedsiębiorców rolnych można znaleźć w analizach zespołu Justyny Góral [2015], w którym podejmowana jest kwestia subsydiów, ekonomiki, finansów i dochodów gospodarstw rolniczych. Autorzy raportu zwracają uwagę na kilka istotnych cech rolnictwa i produkcji rolnej, które skutkują potrzebą interwencjonizmu w tym sektorze, a są to m.in.:

- Ścisły związek procesów produkcyjnych z ziemią, która cechuje się sztywnością podaży, brakiem substytutów czy chociażby niemobilnością; dodatkowo spełnia ona funkcje przyrodnicze i środowiskowe,

- wyższy poziom ryzyka i niepewności produkcji rolnej (chociażby przez związek z czynnikiem ziemi), jej sezonowość, wolniejszy obrót kapitału czy rozproszenie drobnych producentów rolnych,

- sztywny popyt wobec zmian cen i dochodów na rynkach rolnych, a także rozwieranie się nożyc cenowych; dodatkowo dla rolnictwa charakterystyczny jest efekt Kinga, który polega na uzyskiwaniu wyższych dochodów w okresach nieurodzaju, w stosunku do okresów dobrych zbiorów, a to z kolei jest skutkiem niskiej elastyczności cenowej popytu na żywność,

- specyficzny czynnik pracy, gdy łączone jest gospodarstwo rolne i domowe, z czego wynika często rodzinny charakter zatrudnienia, a także mała mobilność mieszkańców wsi [Góral 2015] ${ }^{10}$. Interesujące, szeroko zakrojone badania w tym zakresie przeprowadził także Piotr Kułyk [2013].

Z kolei Ryszard Kata [2011] stwierdził, że wsparcie rolnictwa w ramach WPR z jednej strony zwiększyło płynność finansową rolników i zmniejszyło zapotrzebowanie na kredyt obrotowy, z drugiej jednak wiele działań z funduszy Unii Europejskiej wymagało zaciągania przez rolników kredytów, a zatem ogólny poziom zadłużenia wzrósł [Kata 2011].

Jak zauważył Michał Soliwoda [2014], „Problematyka bezpieczeństwa finansowego gospodarstw rolniczych wymaga uwzględnienia coraz bardziej skomplikowanego tha społecznego przemian na wsi”. Należy zgodzić się z Soliwoda, że niezbędne jest wprowadzenie w gospodarstwach rolniczych przynajmniej uproszczonej ewidencji księgowej (książka przychodów i rozchodów w ujęciu kasowym) [Soliwoda 2014]. Byłby to krok milowy we włączaniu rolników w aktywne zarządzanie finansami gospodarstw/przedsiębiorstw rolniczych. Zresztą na kwestię specyfiki dochodów uzyskiwanych w gospodarstwach rolnych

\footnotetext{
${ }^{10}$ Część z wymienionych cech specyficznych rolnictwa porusza w swoim artykule także Joseph E. Stiglitz [1987].
} 
(zwanych niekiedy chłopskimi), a także na znaczną ich rozpiętość - większą niż w innych grupach społecznych - uwagę zwracał Józef Stanisław Zegar [1999, 2002]. Kwestie dochodowe rolników z gospodarstw indywidualnych badane były w kolejnych latach, m.in. przez zespół Zbigniewa Floriańczyka [2006], Aldonę Zawojską [2006], Edwarda Majewskiego [Majewski i in. 2009], zespół Walentego Poczty [Poczta, Czubak i Pawlak 2010], zespół Danuty Zawadzkiej [Zawadzka, Strzelecka i Szafraniec-Siluta 2013], Andrzeja Czyżewskiego i Martę Guth [2016] czy zespół Bazylego Czyżewskiego [2016].

Kolejnym trudnym do jednoznacznego rozstrzygnięcia zagadnieniem jest kwestia inwestycji i innowacji w rolnictwie oraz ich efektywności. Jak zasygnalizowano wcześniej, nieco inaczej będzie rozpatrywana z perspektywy gospodarstwa rolniczego (rodzinnego, tzw. chłopskiego), inaczej z perspektywy przedsiębiorstwa rolniczego (w którym następuje rozdzielenie gospodarstwa domowego od miejsca pracy zarobkowej w rolnictwie). Jak wynika $\mathrm{z}$ analiz zespołu Wojciecha Józwiaka [2014], około 20\% badanych gospodarstw nie miało zdolności konkurencyjnej. Z kolei Roman Kisiel i Karolina Babuchowska [2013] stwierdzili, że wzrost nakładów inwestycyjnych w polskich gospodarstwach rolniczych dokonuje się nierównomiernie. Niezbędna jest zatem identyfikacja potrzeb innowacyjnych i inwestycyjnych podmiotów agrobiznesu. Szerokie badania z tego zakresu przeprowadzili Wasilewski i Wasilewska [2016], którzy zwracali we wstępie uwagę na znaczny zakres modernizacji polskiego sektora rolno-spożywczego po 1990 roku, jednocześnie sygnalizując, że co prawda działalność inwestycyjna wyraźnie podniosła potencjał produkcyjny sektora rolnego, jednak nie jest on w pełni wykorzystywany w poszczególnych branżach. Najmniejsze wykorzystanie zdolności produkcyjnych cechowało sektor mięsny - ubój bydła i produkcje konserw (potencjał wykorzystany w 25-30\%), najwyższe występuje w pierwotnym przetwórstwie zbóż - przechowalnictwie, produkcji makaronów i pasz - przeciętnie 70-75\%) [Wasilewski i Wasilewska 2016]. Ostatecznie finansiści przygotowali rekomendacje dla przedsiębiorców, ze szczególnym zaznaczeniem potrzeby:

- $\quad$ stworzenia platformy internetowej pozwalającej na branżowe rozważania na temat innowacji w rolnictwie,

- rekomendowania wprowadzenia zmian w zakresie zwiększenia możliwości ulg i odliczeń podatkowych $\mathrm{z}$ tytułu prowadzonych prac $\mathrm{B}+\mathrm{R}$, przy jednoczesnym wskazywaniu potrzeby pełnego wykorzystywania potencjału produkcyjnego,

- usuwania przeszkód i barier w prowadzeniu działalności innowacyjnej,

- poszerzenia informacji statystyki masowej (GUS) w zakresie innowacji, ze szczególnym uwzględnieniem ujęcia branżowego [Wasilewski i Wasilewska 2016]. 
Efektem wdrażanych innowacji powinno być zwiększenie konkurencyjności tak pojedynczego przedsiębiorcy agrobiznesu, jak i całych sektorów. Problematyce budżetowych podstaw poprawy konkurencyjności polskiego rolnictwa poświęcone zostały badania zespołu Kulawika [2014]. Interesującymi stwierdzeniami są niepokój o budowanie strategii konkurencyjności polskiego rolnictwa głównie na bazie rozległego subsydiowania oraz uznanie tego procesu za niebezpieczny [Kulawik red. 2014]. Z kolei Jerzy Wilkin podkreślał, że polskie rolnictwo opłaca się dotować. Charakteryzuje się ono bowiem niską wydajnością, z czasem jednak pojawiają się nowoczesne gospodarstwa, rozwojowe i konkurencyjne, które umożliwia generowanie przyzwoitych dochodów [Wilkin 2014].

Dalszą konsekwencją podejmowania problematyki innowacyjności polskiego rolnictwa jest zagadnienie efektywności inwestycji w rolnictwie, ze szczególnym uwzględnieniem dwóch nurtów: energetycznego i ekologicznego. Obydwa te obszary pozostają w polu ścisłego zainteresowania kreatorów WPR i definiują w znacznym stopniu możliwości uzyskania wsparcia finansowego w rolnictwie od spełnienia założeń, a zatem i poziom dochodu (zysku) z prowadzonej działalności gospodarczej.

Kwestię inwestycji w energetykę odnawialną podejmował w ostatnich latach zespół Mariana Podstawki, dowodząc, że znaczna zmienność polityki w zakresie preferencyjnego finansowania inwestycji w biogazownie rolnicze, duże koszty w fazie początkowej funkcjonowania biogazowni oraz brak stałości i przewidywalności cen certyfikatów energetycznych, zasadniczo znacząco ograniczają, a czasami uniemożliwiają dokończenie procesu inwestycyjnego, nie wspominając już o uzyskiwaniu korzyści z tego typu działalności. Finansiści konkludują jednak, że pomysł tworzenia kolejnych biogazowni rolniczych jest ważny zarówno z punktu widzenia społecznego, jak i ekonomicznego [Podstawka, Gołasa i Bieńkowska-Gołasa 2014], chociaż dowodzą, że prowadzenie takiej działalności może być nieopłacalne [Podstawka i Gołasa 2015].

Kolejnym niezwykle złożonym problemem jest ewidencja księgowa działalności rolniczej. Problematyką tą od dziesięcioleci zajmuje się Tomasz Kondraszuk, a jednym z efektów jego prac było zaproponowanie koncepcji CZARY, która jako spójny system zawiera kilka etapów postępowania, a owe „etapy postępowania łączą cele rachunkowości, obowiązujące zasady, akceptację (wybór), realizację i analizę. Zamiast pojedynczych decyzji o wyborze dopuszczalnych przepisów pojawia się CZARA polityki rachunkowości zawierająca system wzajemnie powiązanych i uzupełniających się elementów" [Kondraszuk 2012, 2013]. Z koncepcją ewidencji księgowej działalności rolniczej wiąże się również problem wyceny składników majątkowych gospodarstwa/przedsiębiorstwa rolniczego. Ponownie podkreślić należy, że szczególnie trudny do rozstrzygnięcia w jednostkach łączących miejsce zamieszkania i pracy. Pojawiają się ponadto kwe- 
stie wyceny składników użytkowanych przez dłuższy czas, a uzyskanych przez rolnika wraz z sukcesją gospodarstwa, czy też składników majątkowych wytworzonych samodzielnie $\mathrm{w}$ gospodarstwie i służących realizacji procesu produkcyjnego. Również i te kwestie poruszane są w badaniach osób specjalizujących się w problematyce podmiotów rolniczych. Niezwykle trudnym do wyceny - choć takie próby były już podejmowane - jest koszt kapitału własnego przedsiębiorstwa rolniczego. Z badań wynika, że znaczna część przedsiębiorców traktuje kapitał własny jako darmowe źródło finansowania [Franc-Dąbrowska i Kobus 2012]. Wydaje się to podejściem nieuzasadnionym, co więcej w postrzeganiu kapitału własnego jako darmowego, pomija się kwestię zagrożeń mogących powodować uszczuplenie tego kapitału, a zatem nie wycenia się ryzyka związanego z zaangażowaniem kapitału własnego. Podobne badania w odniesieniu do gospodarstw rolniczych prowadziła Joanna Bereżnicka [2013], stwierdzając, że lepsze efekty finansowe uzyskiwali przedsiębiorcy wspierający działalność zobowiązaniami niż ci, którzy unikali długu. W efekcie potwierdzone zostało zjawisko awersji do ryzyka przedsiębiorców rolnych - szczególnie tych prowadzących rodzinne gospodarstwa rolnicze [Bereżnicka 2013]. Podobne kwestie poruszała także Magdalena Mądra-Sawicka [2015], czy Danuta Zawadzka [2009].

Dyskutowanym od dłuższego już czasu zagadnieniem finansowym dotyczącym gospodarstw i przedsiębiorstw rolniczych jest kwestia finansowych skutków wprowadzenia podatku dochodowego. Jest to zagadnienie, które wraz z kwestią ujednolicenia zasad opodatkowania podatkiem VAT (bez pozostawienia preferencji w postaci rolników ryczałtowo rozliczających się z VAT), jak również likwidacją lub ograniczeniem korzystania z KRUS, wzbudza ogromne emocje społeczne. Powstały opracowania dotyczące finansowych skutków wprowadzenia podatku dochodowego w rolnictwie, z których wynika, że takie opodatkowanie nie musi oznaczać pogorszenia się sytuacji finansowej rolnika i jego rodziny. Jak wynika z badań zespołu Wasilewskiego, kwestia opodatkowania działalności rolniczej w Polsce wymaga ostatecznego uregulowania, a jednym z argumentów za tym jest zasada sprawiedliwości podatkowej (wyrównująca szanse prowadzenia działalności) [Wasilewski i in. 2015]. Badania z tego zakresu prowadzili również Anna Deresz i Marian Podstawka [2013] oraz Magdalena Mądra [2011], której wyniki badań wskazują, że preferowaną przez rolników podstawą naliczania podatku rolnego byłby dochód rolniczy $\mathrm{z}$ gospodarstwa rolnego skorygowany o koszty pracy własnej. Świadczy to zdaniem finansistki o konieczności uwzględniania aspektu dochodowości działalności gospodarstwa w konstrukcji tego podatku [Mądra 2011]. Kwestie wpływu opodatkowania rolników podatkiem dochodowym na sytuację ekonomiczną gospodarstw rolniczych podejmowali także Andrzej Czyżewski i Katarzyna Smędzik [2011]. Poruszane są również problemy dotyczące systemu ubezpieczeń rolniczych ze szczególnym uwzględnieniem 
warunków demograficznych. Efektem przeprowadzonych badań było stwierdzenie, że w najbliższym dziesięcioleciu rolniczy system emerytalny będzie napotykał bariery demograficzne, co przemawia za koniecznością rozpoczęcia radykalnych zmian w tym systemie. Co więcej, stwierdzono, że jednym z kierunków reformy KRUS powinno być zwiększenie udziału ubezpieczonych w finansowaniu świadczeń emerytalno-rentowych, ze względu na niekorzystne relacje między ludnością płacącą składki a ludnością pobierającą świadczenia z systemu KRUS oraz postępującym procesem starzenia się społeczeństwa wiejskiego [Podstawka i Pawłowicz-Tyszko 2011]. Należy w pełni zgodzić się z tą opinią i wskazać potrzebę dalszego zgłębiania tego obszaru badań [Wilkin 2010].

Dodatkowym obszarem badań wynikającym bezpośrednio ze specyfiki działalności rolniczej i uzależnienia jej efektów od warunków przyrodniczych czy gospodarowaniem z organizmami żywymi (roślinami i zwierzętami) jest kwestia ryzyka $w$ rolnictwie. Tym trudnym obszarem $w$ wieloletnich badaniach zajmuje się Irena Jędrzejczyk [2008a, 2010], łącząc ponadto - wraz z zespołem - trudne kwestie ryzyka ze złożoną problematyką wpływu WPR na obszary wiejskie [Jędrzejczyk 2008b].

\section{Problemy świata finansów agrobiznesu - kierunki dalszych badań}

Szeroki zakres badań prowadzony w obszarze finansów agrobiznesu nie pozwolił dotychczas na rozstrzygnięcie wszystkich problemów nurtujących naukowców i przedsiębiorców rolnych. W kolejnych latach nadal aktualnymi pozostają kwestie zatorów płatniczych charakterystycznych dla polskiej gospodarki, a jednocześnie dotkliwie odczuwalnych $\mathrm{w}$ podmiotach rolniczych. W ocenie autorki warto byłoby podjąć próbę klasyfikacji podmiotów agrobiznesu i ustalenia dedykowanych im zakresów wskaźników płynności - rozgraniczając gospodarstwa rolnicze funkcjonujące w skali mikro, gospodarstwa/przedsiębiorstwa rolnicze produkujące w niezbyt szerokim zakresie, a także przedsiębiorstwa rolnicze i podmioty agrobiznesu funkcjonujące na dużą skalę. Mimo że próby takie były już podejmowane, nie przygotowano dotychczas całościowego projektu w tym zakresie.

Kolejnym obszarem, który wymaga dalszego zgłębiania, jest problem źródeł finansowania podmiotów agrobiznesu. Duże zróżnicowanie tej grupy przedsiębiorstw, a także wieloletnie preferencyjne kredytowanie czy też dotowanie podmiotów rolniczych, skutkują nieco innym podejściem przedsiębiorców rolnych niż tych funkcjonujących poza agrobiznesem. Rodzi to problem unikania zadłużania gospodarstw rolniczych, a tym samym zmniejszania pozycji konkurencyj- 
nej takich podmiotów. W ocenie autorki - podobnie jak w obszarze płynności - warto byłoby poszerzać zakres badań dotyczących zadłużenia, jego wpływu na procesy innowacyjne i pozycję konkurencyjną podmiotów agrobiznesu z uwzględnieniem ich szczegółowej klasyfikacji.

Dalszą konsekwencją wskazanych zakresów badań jest poszukiwanie narzędzi umożliwiających identyfikację podmiotów w rolnictwie zagrożonych bankructwem, a także kosztów i korzyści związanych z tym procesem. Bankructwo gospodarstw rolniczych funkcjonujących w skali mikro, których działalność pozwala na zaspokojenie podstawowych potrzeb rolnika i jego rodziny będzie bowiem w wielu wypadkach skutkowało ubóstwem takich rodzin i zmniejszeniem szans na rozwój dzieci i młodzieży z tych gospodarstw. Podobnie przedstawia się sytuacja większych przedsiębiorstw, które zapewniają miejsca pracy okolicznym mieszkańcom. Jest to problem trudniejszy do rozwiązania niż w wypadku przedsiębiorstw funkcjonujących w większych miejscowościach, gdyż mobilność rolników i ich rodzin jest ograniczona. W Polsce powstały i pozostają nadal (choć w mniejszym tempie) strefy ubóstwa trudne do wyeliminowania z życia gospodarczego.

Gorącą dyskusję wzbudza i zapewne będzie jeszcze wywoływać kwestia wprowadzenia opodatkowania rolników podatkiem dochodowym. Jak każde rozwiązanie także i to ma swoje zalety i wady, warto więc pogłębiać badania $\mathrm{w}$ tym zakresie i być może wdrożyć ten podatek w rolnictwie, tym samym zastępując nim podatek rolny. Wymaga to jednak rozstrzygnięcia kolejnych kwestii dotyczących gospodarstw i przedsiębiorstw rolniczych nieprowadzących ewidencji księgowej, a zatem zakresu i zasad wyceny majątku (także tego, który własnymi siłami rolnika, jego rodziny i pracowników powstał w takiej jednostce). Kolejno pociagga to za sobą zastanowienie się nad problemem zasad wyceny kosztu zużycia takich składników majątku, a zatem ich odpisów amortyzacyjnych. Opodatkowanie gospodarstwa rodzinnego, w którym dom rodzinny i siedziba firmy to jedno, wymaga rozstrzygnięcia problemu rozliczenia niektórych kosztów np. zużytej energii, na tę związaną z procesem produkcyjnym i pracą rolnika oraz jego rodziny i tę związaną z użytkowaniem gospodarstwa rolniczego jako miejsca zamieszkania. Następnymi problemami związanymi z opodatkowaniem rolników podatkiem dochodowym są kwestia zasad zatrudniania członków rodziny i sposobu rozliczenia wynagrodzeń, a także sposób rozliczenia dotacji. Badania w tym obszarze były prowadzone i trwają, wymagaja jednak dalszego zgłębiania w finansach agrobiznesu.

Podobnie problematyczną kwestią jest przejście wszystkich przedsiębiorców na opodatkowanie podatkiem od towarów i usług wymagającego prowadzenie pełnej ewidencji księgowej, bez utrzymywania dotychczasowych preferencyjnych rozliczeń, w wypadku zakupu płodów rolnych od rolnika ryczałtowego. 
Dużo emocji wzbudza również kwestia ubezpieczenia rolników i ich rodzin w KRUS. Nie ma jak dotychczas jednoznacznych rozstrzygnięć co do konieczności utrzymania, likwidacji, czy też częściowego utrzymania uprzywilejowania rolnictwa, czy też jego części w tym zakresie. Mimo badań i sugerowanych rozwiązań zasad ubezpieczania rolników, jest to kolejne zagadnienie, które wymaga kontynuacji badań.

Zasadniczym obszarem badań całościowo traktującym zagadnienia finansowe $\mathrm{w}$ podmiotach rolniczych jest znaczne zróżnicowanie przedsiębiorstw, a tym samym odmienny poziom ryzyka charakteryzujący takie jednostki. Zakres zagrożeń cechujących przedsiębiorstwa w rolnictwie jest bardzo szeroki, inne bowiem zagrożenia dotyczą przedsiębiorstw zajmujących się wyłącznie produkcją roślinną, roślino-zwierzęcą, czy zwierzęcą - również silnie zróżnicowaną w zależności od gatunku zwierząt. Zatem finanse agrobiznesu jawią się jako zakres tematyczny bardzo szeroki, wyraźnie zróżnicowany wewnętrznie i wymagający dalszych, obszernych badań.

\section{Podsumowanie}

Reasumując, należy stwierdzić, że poczynając od rozważań koryfeuszy finansów agrobiznesu, poprzez prowadzone na przełomie XX i XXI wieku badania, nie udało się rozstrzygnąć wszystkich wątpliwości z obszaru podejmowania decyzji finansowych i ich skutków w rolnictwie. Nadal pozostaje szerokie pole badawcze - a wręcz wraz ze wzrostem tempa przemian w gospodarce w skali makro, jak i w świecie - pojawia się coraz więcej wątpliwości dotyczących rozstrzygnięć dedykowanych przedsiębiorcom rolnym. Rysuje się zatem szeroki zakres badawczy, który można byłoby określić jako finanse agrobiznesu, nacechowany specyfiką, w tym szczególnie uzależnieniem produkcji od gospodarowania z organizmami żywymi, silnym uzależnieniem od czynników przyrodniczych, czy ograniczoną mobilnością społeczeństwa $z$ terenów wiejskich. Jednocześnie należy pamiętać, że rolnictwo jako dział gospodarki zajmujący się zapewnieniem bezpieczeństwa żywnościowego kraju powinien pozostawać w kręgu szczególnych zainteresowań świata finansów.

\section{Literatura}

ADAMSKAA., MĄCZYŃSKA E. (red.), 2013: Upadłości, bankructwa i naprawa Przedsiębiorstw, Oficyna Wydawnicza SGH, Warszawa. 
BEREŻNICKA J., 2013: Wzrost i rozwój gospodarstw rodzinnych - studium teoretyczno-empiryczne, Rozprawy Naukowe i Monografie 414, Wydawnictwo SGGW, Warszawa.

BEREŻNICKA J., 2013: Role of Debt and the Ability to Create Equity in a Family Farm, Management and Production Engineering Review 4, 2, 3-11.

BORATYŃSKA K., 2010: Poziom obciażeń podatkowych a zagrożenie bankructwem przedsiębiorstw piwowarskich. Zeszyty Naukowe Szkoły Głównej Gospodarstwa Wiejskiego. Ekonomika i Organizacja Gospodarki Żywnościowej 82, 33-45.

BORKOWSKI B., 2006: Życie i twórczość prof. dr hab. Teresy Marszałkowicz (1924-1998), Zeszyty Naukowe Szkoły Głównej Gospodarstwa Wiejskiego. Ekonomika i Organizacja Gospodarki Żywnościowej 60, 7-13.

CORNELISSE P.A., van DIJK H.K., 2006: Jan Tinbergen (1903-1994), Econometric Institute Report EI 2006-09:1-10.

CZYŻEWSKI A., SMĘDZIK K., 2011: Wpływ opodatkowania dochodów rolniczych na sytuację ekonomiczna indywidualnych gospodarstw rolnych z obszaru intensywnego rolnictwa (próba symulacji w odniesieniu do gospodarstw FADN z powiatu gostyńskiego), Zeszyty Naukowe Szkoły Głównej Gospodarstwa Wiejskiego. Ekonomika i Organizacja Gospodarki Żywnościowej 92, 5-16.

CZYŻEWSKI A., GUTH M., 2016: Zróżnicowanie produkcji mleka w makroregionach Unii Europejskiej z wyróżnieniem Polski, Wydawnictwo Naukowe PWN, Warszawa.

CZYŻEWSKI B. (red.), 2016: Political rents of European farmers in the sustainable development paradigm, Wydawnictwo Naukowe PWN, Warszawa.

DERESZ A., PODSTAWKA M., 2013: Opodatkowanie podatkiem dochodowym od osób fizycznych mikroprzedsiębiorców $w$ warunkach kryzysu, Prace Naukowe Uniwersytetu Ekonomicznego we Wrocławiu 306, 73-85.

FLEJTERSKI S., ŚWIECKA B. (red.), 2005: Elementy finansów i bankowości, CeDeWu. $\mathrm{pl}, 18$.

FLORIAŃCZYK Z., 2006: Wyniki ekonomiczne polskiego rolnictwa w ujęciu europejskim i regionalnym, Raport PW 43, IERiGŻ-PIB, Warszawa.

FRANC-DĄBROWSKA J., 2006: Poziomy wyniku finansowego miara sytuacji finansowej przedsiębiorstw w warunkach rozwoju zrównoważonego, Zeszyty Naukowe Akademii Rolniczej we Wrocławiu, Rolnictwo 87 (540), 149-156.

FRANC-DĄBROWSKA J., 2008a: Ocena plynności finansowej przedsiębiorstw rolniczych, Zagadnienia Ekonomiki Rolnej 1 (314), 43-59.

FRANC-DĄBROWSKA J., 2008b: Jak ksztaltowano plynność szybka i natychmiastowa w przedsiębiorstwach rolniczych?, Zeszyty Naukowe Szkoły Głównej Gospodarstwa Wiejskiego. Ekonomika i Organizacja Gospodarki Żywnościowej 64, 39-51.

FRANC-DĄBROWSKA J., 2009: Praktyczne zastosowanie wybranych modeli panelowych do oceny sytuacji finansowej przedsiębiorstw rolniczych, Zeszyty Naukowe Szkoły Głównej Gospodarstwa Wiejskiego. Ekonomika i Organizacja Gospodarki Żywnościowej 76, 31-40.

FRANC-DĄBROWSKA J., KOBUS P., 2012: Koszt kapitału wtasnego - dylematy wyceny, Zagadnienia Ekonomiki Rolnej 1, 77-89.

GÓRAL J. (red.), 2015: Subsydia a ekonomika, finanse i dochody gospodarstw rolniczych (1), Raport PW 4. IERiGŻ-PIB, Warszawa. 
JAJUGA K., 2013: Nauka o finansach - nowe wyzwania metodyczna, IX Kongres Ekonomistów Polskich, http://www.pte.pl/kongres/referaty/Jajuga\%20Krzysztof/Jajuga\%20Krz ysztof $\% 20 \% 20$ NAUKA $\% 200 \% 20$ FINANSACH $\% 20 \%$ E2\%80\%93\%20NOWE $\% 20 \mathrm{w}$ yzwania\%20metodyczne.pdf [dostęp: 20.11.2016], 1-14.

JĘDRZEJCZYK I., 2008a: Identyfikacja ryzyka na potrzeby ochrony ubezpieczeniowej sektora rolnego, Rozprawy Ubezpieczeniowe, 1896-3641, 1, 17-30.

JĘDRZEJCZYK I. (red.), 2008b: Ocena komplementarności działań Polityki Spójności, Wspólnej Polityki Rolnej i Wspólnej Polityki Rybackiej na obszarach wiejskich, Wydawnictwo SGGW, Warszawa.

JĘDRZEJCZYK I., 2010: Inwestycje ochronne w ograniczaniu skutków ryzyka powodzi rola prewencji, Wiadomości Ubezpieczeniowe 2, 49-72.

JÓZWIAK W. (red.), 2014: Efektywność, koszty produkcji i konkurencyjność polskich gospodarstw rolnych obecnie i w perspektywie średnio- oraz dtugoterminowej, Raport PW 144, IERiGŻ-PIB, Warszawa.

KAHNEMAN D., TVERSKY A., 1979: Prospect Theory: An Analysis of Decision Under Risk, Econometrica 47, 2, 263-292.

KATA R., 2011: Wplyw polityki fiskalnej i monetarnej na zadtużenie gospodarstw rolnych $w$ Polsce, Roczniki Nauk Rolniczych Seria G 98, 3, 73-83.

KISIEL R., BABUCHOWSKA K., 2013, Naktady inwestycyjne w gospodarstwach rolnych - ujęcie regionalne, Roczniki Ekonomii Rolnictwa i Rozwoju Obszarów Wiejskich $100,1,62-69$.

KISIELIŃSKA J., 2008: Modele klasyfikacyjne prognozowania sytuacji finansowej gospodarstw rolniczych, Rozprawy Naukowe i Monografie 333, Wydawnictwo SGGW, Warszawa.

KONDRASZUK T., 2012: CZARA tworzenia i implementacji polityki rachunkowości a projekt KSR $n r$ 7, Zawartość informacyjna polityki rachunkowości: wybrane problemy, (red.) Helena Żukowska, Bogna Sawicka, Wydawnictwo KUL, Lublin, 65-78.

KONDRASZUK T., 2013: CZARA polityki rachunkowości w kontekście fundamentalnych zasad sporzadzania sprawozdań finansowych, Studia i Prace Kolegium Zarządzania i Finansów, Szkoła Główna Handlowa w Warszawie, 130, 29-38.

KULAWIK J. (red.), 2013: Dopłaty bezpośrednie i dotacje budżetowe a finanse oraz funkcjonowanie gospodarstw i przedsiębiorstw rolniczych (3), Raport PW 46, IERiGŻ-PIB, Warszawa.

KULAWIK J. (red.), 2014: Budżetowe podstawy poprawy konkurencyjności polskiego rolnictwa (synteza), Raport PW 143, IERiGŻ-PIB, Warszawa.

KUŁYK P., 2013: Finansowe wsparcie rolnictwa w krajach o różnym poziomie rozwoju gospodarczego, Wydawnictwo Uniwersytetu Ekonomicznego w Poznaniu.

MĄDRA M., 2011: Zróżnicowanie obciqżenia podatkiem rolnym indywidualnych gospodarstw rolniczych $w$ zależności od sity ekonomicznej, Zeszyty Naukowe Uniwersytetu Szczecińskiego 640 (38), Finanse, Rynki Finansowe, Ubezpieczenia 38, 640 (38), 147-156.

MĄDRA-SAWICKA M., 2015: Znaczenie wewnętrznych źródet finansowania w ksztaltowaniu struktury kapitału przedsiębiorstw rolniczych, Zarządzanie Finansami i Rachunkowość 3, 4, 87-98. 
MAJEWSKI E., WA¿S A., SULEWSKI P., CYGAŃSKI Ł, 2009: Ryzyko dochodowe w kontekście zmian WPR - analiza scenariuszy, [w:] M. Hamulczuk, S. Stańko (red.), Zarzqdzanie ryzykiem cenowym a możliwości stabilizowania dochodów producentów rolnych - aspekty poznawcze i aplikacyjne. IERiGŻ-PIB, Warszawa, 109-134.

MALINOWSKI M., 2016: Historia pieniqdza: co byto na poczatku?, Silva Rerum, Pasaż Wiedzy Muzeum Pałacu Króla Jana III w Wilanowie, http://www.wilanow-palac.pl/historia_pieniadza_co_bylo_na_poczatku.html [dostęp: 27.04.2016].

MAŃKO S., SOBCZYÝNSKI T., SASS R., 2008: Zmiany poziomu zrównoważenia plynności finansowej $w$ gospodarstwach rolniczych UE w latach 1989-2005, Zeszyty Naukowe Szkoły Głównej Gospodarstwa Wiejskiego. Ekonomika i Organizacja Gospodarki Żywnościowej 64, 5-22.

MARKOWITZ H., 1952: Portfolio Selection, The Journal of Finance 7, 1, 77-91.

MILlER M.H., MODIGLIANI F., 1961: Dividend Policy, Growth and the Valuation of Shares, [in:] The Journal of Business 4, 411-433.

MODIGLIANI F., M. H. MILLER, 1958, The Cost of Capital, Corporation Finance and the Theory of Investment, The American Economic Review 18, 3, 261-297.

MODIGLIANI F., MILLER M.H., 1963: Corporate Income Taxes and the Cost of Capital: A Correction, [in:] The American Economic Review 3, 433-443.

OWSIAK S., 2013: Dylematy interpretacyjne przy ocenie sytuacji finansowej państwa, IX Kongres Ekonomistów Polskich, http://www.pte.pl/kongres/referaty/Owsiak\%20Stanis\%C5\%82aw/Owsiak\%20Stanis\%C5\%82aw\%20\%20DYLEMATY\%20INTERP RETACYJNE\%20PRZY\%20OCENIE\%20SYTUACJI\%20FINANSOWEJ\%20PA \%C5\%83STWA.pdf [dostęp: 20.11.2016], 1-20.

POCZTA W., CZUBAK W., PAWLAK K., 2009: Zmiany $w$ wolumenie produkcji i dochodach rolniczych $w$ warunkach akcesji Polski do UE, Zagadnienia Ekonomiki Rolnej 4, 40-52.

PODSTAWKA M., DERESZ A., 2009: Ocena funkcjonowania podatku od dochodów osób fizycznych oraz propozycji jego zmian w latach 2009-2012, Zeszyty Naukowe Szkoły Głównej Gospodarstwa Wiejskiego. Polityki Europejskie, Finanse i Marketing 2, 51, 149-162.

PODSTAWKA M., GOŁASA P., BIEŃKOWSKA-GOŁASA W., 2014: Potencjat produkcji biogazu rolniczego $w$ województwie pomorskim i jego wykorzystanie, Zeszyty Naukowe Szkoły Głównej Gospodarstwa Wiejskiego. Ekonomika i Organizacja Gospodarki Żywnościowej 107, 155-162.

PODSTAWKA M., PAWŁOWSKA-TYSZKO J., System rolniczych ubezpieczeń spolecznych a uwarunkowania demograficzne, Zeszyty Naukowe Szkoły Głównej Gospodarstwa Wiejskiego. Ekonomika i Organizacja Gospodarki Żywnościowej 94, 87-98.

PODSTAWKA M., GOŁASA P., 2015: Ekonomiczne uwarunkowania energetyki prosumenckiej na przykładzie mikrobiogazowni rolniczej, Roczniki Naukowe SERiA 17, 6, 223-227.

SAH R.K., STIGLITZ J.E., 1987: The Taxation and Pricing of Agricultural and Industrial Goods in Developing Economies [In:] The Theory of Taxation for Developing Countries, D.M.G. Newbery, N.H. Stern (eds.). 16, 426-461. Oxford University Press, New York.

SOLIWODA M., 2014, Bezpieczeństwo finansowe gospodarstw rolniczych $w$ Polsce z perspektywy Wspólnej Polityki Rolnej, Wieś i Rolnictwo 3, 16,: 45-55. 
STIGLITZ J.E., 1987: Some Theoretical Aspects of Agricultural Policies, The World Bank Research Observer 2, 1, 43-60.

SULEWSKI P., 2015: Awersja do ryzyka a skłonność rolników do wprowadzania zmian w gospodarstwach rolnych, Roczniki Naukowe Ekonomii Rolnictwa i Rozwoju Obszarów Wiejskich 102, 4, 41-49.

SZALENIEC M., 2009: Nobliści, Narodowy Bank Polski, http://www.nbportal.pl/wiedza/artykuly/historia-mysli-ekonomicznej/noblisci [dostęp: 12.11.2016].

Świat Druku The World of Printing, 2009: http://archiwum.swiatdruku.eu, [dostęp: 27.04.2016].

WASILEWSKI M., GAŁECKA A., 2010: Płynność finansowa gospodarstw rolniczych położonych w województwie lubelskim, Zeszyty Naukowe Szkoły Głównej Gospodarstwa Wiejskiego. Ekonomika i Organizacja Gospodarki Żywnościowej 82, 267-279.

WASILEWSKI M., MĄDRA-SAWICKA M., GANC M., GRUZIEL K., 2015: Finansowe skutki wprowadzenia podatku dochodowego w indywidualnych gospodarstwach rolniczych, Wydawnictwo SGGW, Warszawa.

WASILEWSKI M., WASILEWSKA A., 2016: Stan, kierunki i efektywność innowacji w przedsiębiorstwach przetwórstwa rolno-spożywczego, Wydawnictwo Szkoły Głównej Gospodarstwa Wiejskiego, Warszawa.

WIGIER M., 2013: Model rozwoju rolnictwa polskiego $w$ świetle efektów realizacji WPR, Zagadnienia Ekonomiki Rolnej 1 (334), 23-41.

WILKIN J., 2010: KRUS posiadaczy ziemskich, Gazeta Wyborcza (wyd. zasadnicze). 0860$-908 X$. 63, 17.

WILKIN J., 2014: Wilkin o 25-leciu: polskie rolnictwo optaca się dotować, http://wyborcza. pl/1,91446,16068282,Wilkin_o_25_leciu_polskie_rolnictwo_oplaca_sie_dotowac. html?disableRedirects=true [dostęp: $17.11 . \overline{2016}$ ].

ZAWADZKA D., 2009: Determinanty popytu małych przedsiębiorstw na kredyt handlowy identyfikacja i ocena, Wydawnictwo Uniwersytetu Ekonomicznego w Poznaniu.

ZAWADZKA D., STRZELECKA A., SZAFRANIEC-SILUTA E., 2013: Znaczenie doptat do działalności operacyjnej $w$ tworzeniu dochodu z rodzinnego gospodarstwa rolnego $w$ Polsce, Roczniki Naukowe SERiA 15, 3, 396-402.

ZAWADZKA D., SOBIECH J.,(red.) 2014: Wrost i alokacja aktywów finansowych i rzeczowych rolników (przedsiębiorstw rolniczych i gospodarstw domowych) Pomorza Środkowego, Wydawnictwo Uczelniane Politechniki Koszalińskiej.

ZAWOJSKA A., 2006: Społeczno-ekonomiczne aspekty doptat bezpośrednich w UE, Roczniki Naukowe SERiA 8, 4, 400-404.

ZEGAR J.S., 1999: Problematyka dochodów chłopskich, Organizacja, Ekonomika i Problemy Społeczne 3, 7-27.

ZEGAR J.S., 2002: Kwestia dochodów w rolnictwie chtopski w okresie transformacji, Monografie i Opracowania 498, Oficyna Wydawnicza SGH, Warszawa.

\section{Abstrakt}

Celem artykułu było zebranie dorobku luminarzy finansów agrobiznesu oraz wskazanie na bieżące i przyszłe kierunki badań. Geneza finansów agrobiznesu 
- odrębnego obszaru badań w stosunku do finansów w ogóle - ma swoje umocowanie w specyfice podmiotów funkcjonujących w sferze agrobiznesu. Poczynając od rozważań koryfeuszy finansów agrobiznesu, poprzez prowadzone na przełomie wieków XX i XXI badania, nie udało się rozstrzygnąć wszystkich wątpliwości z obszaru podejmowania decyzji finansowych i ich skutków w rolnictwie. Nadal pozostaje szerokie pole badawcze - a wręcz wraz ze wzrostem tempa przemian w gospodarce w skali makro, jak i w świecie - pojawia się coraz więcej wątpliwości dotyczących rozstrzygnięć dedykowanych przedsiębiorcom rolnym. Rysuje się zatem szeroki zakres badawczy, który można byłoby określić jako finanse agrobiznesu, nacechowany specyfika, w tym szczególnie uzależnieniem produkcji od gospodarowania $\mathrm{z}$ organizmami żywymi, silnym uzależnieniem od czynników przyrodniczych, czy ograniczoną mobilnością społeczeństwa z terenów wiejskich.

Słowa kluczowe: luminarze, finanse, agrobiznes

\section{Luminaries of agribusiness finance, state of the present and prospects}

\section{Abstract}

The aim of this article was to collect the achievements of luminaries of agribusiness finance and to indicate current and future research directions. The origin of finance of agribusiness - a separate area of research in relation to finance in general - has its anchorage in the specificity of entities operating in the sphere of agribusiness. Starting from the debates of coryphaeus of agribusiness finance, through the research conducted at the turn of the 20th and 21st century, all the uncertainties surrounding the financial decision-making and their effects on agriculture have not been resolved. There is still a wide field of research - and even with the increase in the pace of change in the macro-economy and in the world - more and more doubts arise about the decisions dedicated to agricultural entrepreneurs. There is therefore a wide range of research that can be identified as agribusiness finances, characterized by specificities, including the dependence of production on livelihoods, strong dependence on natural factors, and limited mobility of rural populations

Key words: luminaries, finance, agribusiness 